LWSA

PAPER - OPEN ACCESS

\title{
Totem as a Sacred in Chinese Culture Modern Tradition
}

\author{
Author $\quad$ : Celerina Dewi Hartati et al. \\ DOI $\quad: 10.32734 /$ lwsa.v3i4.1124 \\ Electronic ISSN $\quad: 2654-7066$ \\ Print ISSN : :2654-7058
}

Volume 3 Issue 4 - 2020 TALENTA Conference Series: Local Wisdom, Social, and Arts (LWSA)

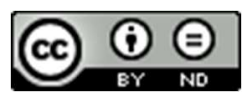

This work is licensed under a Creative Commons Attribution-NoDerivatives 4.0 International License.

Published under licence by TALENTA Publisher, Universitas Sumatera Utara

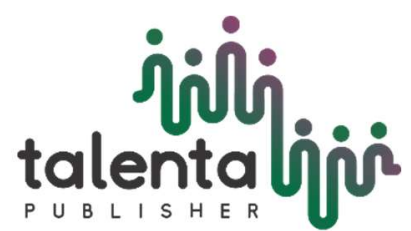




\title{
jibli \\ LWSA Conference Series 03 (2020)

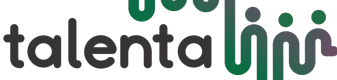

\section{Totem as a Sacred in Chinese Culture Modern Tradition}

\author{
Celerina Dewi Hartati, Yulie Neila Chandra, Gustini Wijayanti, Hin Goan Gunawan \\ Chinese Language and Culture Universitas Darma Persada, Jalan Taman Malaka Selatan Jakarta 13450, Indonesia \\ c.dewihartati@gmail.com,ync.puellabona@gmail.com,gustiniwijayanti_2001@yahoo.com,hingoan_gunawan@yahoo.com
}

\begin{abstract}
In history, the Chinese believed in totems (tuteng 图腾). The totem is a symbol of the ancestors who can protect and prevent disaster. Therefore the totem has an important position in China. The totem is an important part of traditional Chinese culture which represents the human aspiration to drive out evil spirits and achieve a happy life. The totem is a view of life held by the Chinese and is still believed today. This paper will look at the concept of the totem as a sacred view that is believed in Chinese culture in Bekasi, West Java through a form of the deity's birthday ceremony of Hian Thian Siang Tee at the Hok Lay Kiong temple. The method used to collect data for the composition of this article is a qualitative method, by conducting observations and in-depth interview with selected informants which is several reliable informants. Observations were made at Hok Lay Kiong Temple during the preparations and during the deity's birthday Hian Thian Siang Tee ceremony. In this study, through the ceremony at the Hok Lay Kiong temple the use of totems in the religious practices of Bekasi Chinese people is can be seen. The totem can reflect a sacred manifestation such as in the use of the Hian Thian Siang Tee flags. At that moment, these objects become sacred because they are used as a means for the medium to carry out the process of changing from profane to sacred. But in ordinary times, when it is not at ceremonies, these objects are stored and become something profane.
\end{abstract}

Keywords : profane; sacred; totem; tradition.

\section{Introduction}

The concept of the totem as a symbol or marker of a group is closely related to the sacred and profane concepts and ceremonies. Durkheim found the symbol or symbols of the totem animal was very meaningful to the clan who worshiped it, because the animal was not only considered part of the sacred, but also a perfect embodiment and example of the sacred. This attitude can be seen when the clan holds religious ceremonies that always use the symbols of their totem, which are made of wood or stone carvings and placed in the middle of them in the ceremony. For the clan, the totem is the most sacred thing and can communicate its sacredness to the creatures around it.

Totem for Durkheim is an emblem that is external in nature which allows each member of the clan to identify with the totem which can be represented later in the form of a certain design engraved on their body, even in more extreme cases, humans try to personify what the totem represents in in their behavior or actions(1)

The totem is a symbol that states members are relatives. The totem is a symbol of the group, its members are reminded of the existence of the group without this symbol, they will forget their relationship with each other. At the time of the ceremony when the entire group gathers to worship the totem, a reaffirmation of collective importance takes place. By worshiping totems, people worshiped groups. In this way, the totem functions of integration because it integrates social systems, integrates the separate parts together and makes them a unity.

In China history during the Shang dynasty, the rulers of the Shang dynasty (1600-1046 BC) had a totemic relationship with the ten suns which were also considered birds. Totemism as a classification system, rather than a social institution, a way for primitive man to command and understand the world in which he lived and which included analogies between humans and animals or other natural objects(2). 
The Chinese know dragons, phoenixes, fish, birds, wolves, snakes, black turtles, and others as representations of totems that reinforce identity. The worship of gods as a form of communal religion cannot be separated from totemism, because gods or those associated with these gods are considered sacred by a group. The totem symbolizes a group and unites humans with their environment. The totem is a symbol of a group and worship of a god is actually a form of how people express and strengthen their belief in the group and this worship is communal. The Chinese have long known totems in the form of plants and animals which are used as symbols of a clan.

In The Elementary Forms of the Religious Life, Durkheim provides an account of totemic belief in Australia. In his description, it is described that a group of humans feel themselves related to one species of certain natural phenomena, for example kangaroos, eagles, cactus, or even winter. The species with which they are associated is called the totem. The term totemism comes from the word Ojibwa (Algonkin tribe), this term appears to find sacred and religious sources.(3)

These totems become special because they are emblems or symbols. Sacred objects are symbols, the meaning of which is not in the characteristics of the object itself, but is embedded in the things being symbolized by those objects. Totem when presenting something, then the representation itself actually becomes something important, and that representation is what they worship. In other words, totemism is essentially a symbol, or material expression of something else. (4)

The life of the ancestors of the Chinese people believed in totems (tuteng 图腾). The totem is a symbol of their ancestors by assuming who can protect them and prevent disaster, therefore totem animals have an important position in China. In primitive society, because of insecurity, confusion and fear due to disease, plague, death, disaster and so on, people needed some kind of real or imaginary object to help them drive out harsh things, drive out evil spirits, prevent disaster, stay healthy and pursue prosperity, then the supernatural concept comes into being. On this basis, the totem became the embodiment of favorable concepts, and became important in the Chinese cultural component. Based on specific psychological and long-term social practices, the concept of the divine gradually began to increase in pursuit of a better life. Therefore people regard some natural or cultural objects as divine concepts(5).

Existing study about Chinese totem in modern tradition is already done by many researchers, but they show the using of Chinese totem in modern design. Such as Xue Dong stated auspicious patterns and classic model to logo design, inherit and innovate, combine the international design rule with shape, meaning, and spirit of traditional auspicious patterns to entrust new vitality to logo design, then design the work consistent with modern society to call the return of traditional culture. (6). This study intends to show the using of Chinese totem in modern tradition as a sacred in temple's ceremony, especially in deity's birthday ceremony; Hian Thian Siang Tee birthday in Hok Lay Kiong temple Bekasi, West Java.

\section{Research Methods}

This research is an ethnographic method research, so the main technique I used to collect data is participant observation. In carrying out ethnography, not only participant-observation is an important technique for collecting data, but also in-depth interviews. I did the interview at the temple because this is the place where all the people from the temple gather, so it is easier for me not to make appointments and so on. The people of the temple here are the temple administrators, the temple officials or biokong, the temple guards. The location of the research was carried out at the temple in the city of Bekasi, namely the Hok Lay Kiong Temple. I chose the Hok Lay Kiong temple which is located in the city of Bekasi because this temple is the biggest and oldest temple in Bekasi City, West Java.

\section{Results and Discussion}

The totem is a view of life held by the Chinese. The totem has aesthetic value, this can be seen from the works of art and art objects that often display totem forms. Apart from its aesthetic value, the totem is believed to have formidable magical powers. Totems in Chinese culture include dragon, phoenix, fish, bird, wolf, turtle and snake.

There are several types of worship regarding totems in Chinese culture, namely totem worship, reproduction worship, amulet worship. Reproductive worship refers to a culture to maintain the survival and development of an ethnic group, people aspire after having a family to continue their offspring. In Chinese folk culture, the images and patterns of birds, fish, frogs and lotuses carry the profound meaning of worship of reproduction. Amulet worship refers to the worship of the existence of supernatural powers, believed and worshiped by people, especially male gods who are thought to control some parts of nature(7).

The totem is an important part of traditional Chinese culture which represents the human aspiration to drive out evil spirits, to achieve a happy life. The totem has a long history, and is very diverse and is still believed today. The ancestors of the Chinese 
people created many totem images to show their expression of the hope of a happy life. Four examples of traditional totems include the dragon, phoenix, tiger and lion. The symbols of these totems can be found in all temples both in China and Indonesia, becoming part of the architectural art of the temple. Every pillars in the temple are red engraved with a dragon image.

In its history, the Chinese people made special worship of dragons. In the period of uncertainty, the dragon was the symbol of the emperor and imperial power. Everything related to the emperor using the dragon, such as the royal palace is called the dragon palace, the emperor's robe is called the dragon's robe, the son of the emperor is called the boy of the dragon, the face of the emperor is called the face of the dragon, the head of the emperor is called the head of the dragon. The dragon also ranks fifth in the twelve animals in the year of birth. Images of dragons are usually seen on lanterns, dragon boats, bridges, temples, emperor clothing and equipment, and royal buildings. Some people even take the dragon character (龙 Lóng) as their family name; Almost all Chinese parents hope that their son to be a dragon means to be useful, energetic, determined, optimistic, intelligent and ambitious like a dragon.

Dragons are called divine beings who bring abundance, prosperity and good fortune. The dragon totem has existed since Neolithicum times. Many legends tell of the relationship between the dragon and the emperor and some emperors claim to be descended from dragons. In Chinese folk culture, the dragon occupies a very important position, the dragon (long 龙) symbolizes strength and excellence, heroism and courage, heroism and perseverance, glory and divinity.(8)

The dragon consists of nine parts, which include a head like a camel, antlers like a deer, eyes like a rabbit, ears like a bull, a neck like a snake, a stomach like a frog, scales like a goldfish, claws like a tiger, and claw nails like an eagle.(9)Dragons in Chinese culture are seen as symbols of good luck, people dance dragons (barongsai) to pray for good weather in order to achieve a bountiful harvest. Playing kites shaped like spring dragon is also popular among Chinese people. Every second day of the second month of Chinese New Year is the day the dragon heads appear (Dragon Heads Raising Day). This time is believed to be when the dragon wakes up and raises its head. According to legends and there is also the saying èr yuè èr, lóng táitóu (二月二, 龙 抬头) which means the day the two dragons raise their heads. There is a tradition in China, on this day people cut their hair for good luck. (10)

Phoenix exist only in Chinese legends and mythology, and are considered sacred. There is a pair of phoenix, the male bird is called feng and the female bird is called huang, and this pair of birds is usually called together, namely Fenghuang. This mythological animal symbolizes the principle of balance yinyang. Similar to a dragon, this mystical bird is symbolized by the head of a wild goose, the chin of a swallow, the beak of a chicken, the neck of a snake, the body of a turtle, the feathers of a dragon scale, the rump of a female unicorn, the tail of a fish and a peacock. The phoenix is also a symbol of the power of the empress, a symbol of wisdom, kindness, peace, luck and harmony. Therefore, Chinese parents often place their hopes on their daughters to become phoenix. Phoenix become temple decorations.

Lions are a deep image in Chinese culture. The lion statues and symbols can be seen in various forms to have the spirit of avoiding evil. The lion as a totem, lion worship has been developing for a long time. Initially, the Chinese worshiped the lion as the protector of the Tang dynasty, the lion became a symbol of strength.(11) Lion statues of various shapes and textures appear not only in front of office gates, buildings and palaces but also in temples, tombs and bridges. The lion is usually symbolized by a pair, male and female. The front door of the temple always has a pair of male lion statues on the left and a girl on the right as a symbol of the temple guard.

Totems as values, the way of life of Chinese people can be traced through the Encyclopedia of 100 Chinese Surnames (Baijiaxing Daquan 百家姓大全), it is noted that the names of Chinese surnames have their respective totems. In this dictionary, the history of each clan name is explained, the totem of each clan, the place of origin of the clan, the area where the clan name is distributed, the famous people of the clan, the house of the abu marga, the ancestral temple of a clan. From this encyclopedia, it can be seen that the Chinese are a nation that knows the worship of the totem. The totem as a marker of the family name shows the totem's function as a group identity.

In Chinese cosmology there are four mythological animals guarding the four cardinal directions (sixiang 四象), namely the green dragon (qinglong 青龍) in the east, the white tiger (baihu 白虎) in the west, the red que bird (zhuque 朱雀) in the south, and the black turtle and snake (xuanwu 玄武) to the north. As recorded in the Shanhaijing (山海经 The Classic Book of Mountains and Seas), each of the four animals represents the four seasons. The green dragon represents spring, the zhuque bird represents summer, the white tiger represents autumn, and the black turtle represents winter. Black turtles are known as sacred turtles and have the ability to see the future by burning turtle shells, the result of this burning was read by fortune tellers during the Shang dynasty. The black tortoise has the meaning of longevity, brightness and science. Sixiang is the basis for feng shui science because it determines the quality of a place based on four directions. 
These mythological symbols can be seen in traditional temple buildings, especially the green dragon and white tiger can always be found at the entrance to the temple building. Actually, what is depicted as waiting animals is a visualization of the constellations in the sky. Each animal constellation is a grouping of seven different constellations which are considered basic constellations. Overall the basic constellations to $4 \mathrm{x} 7$ in total there are 28 constellations. There is also an opinion which states that the astronomy of the 28 constellations is the influence of Hindu astronomy (Hindu astronomy takes into account 27 constellations)(12)

Hok Lay Kiong Temple, Bekasi with the main deity Hian Tian Siang Tee is a god who is believed to be the ruler of the northern sky. Historical records show that since the time of the Zhou Dynasty (1122- 255 BC) there has been a cult of him. Hian Tian Siang Tee is a designation in the Hokkien language, many Chinese in Indonesia are Hokkien, so there are many names for gods, prayers in Hokkien besides that there are still names in Hakka. Hian Tian Siang Tee or in Chinese is Xuan Tian Shangdi also has many other names. Some of the known names for him that can be associated with totem worship are Hei Di (黑 帝 Black Emperor) as Lord of Heaven and Bei Xing (North star 北星) who is the divine messenger and parent of the northern constellation which ranks first in the constellation and its brightness becomes qibla direction on sky map. Hei which also means black (dark) also indicates 玄天上帝 as the ruler associated with the supervision and conqueror of the dark world (demons \& stealth), which is associated with immortality; who protects and guides in the dark; which becomes the basis for all mysteries and gives way in the metaphysical universe of the universe (according to the explanation of the informant; Mr. Sudrajat). Hian Tian Siang Tee 玄天上帝 as the divine messenger becomes a pillar in all mysteries of the metaphysical realm. Also as a watchdog and judge in life, protect from the dark world.

The black color as a symbol of the north appears on the banner of the Hian Tian Siang Tee greatness flag. In this short ceremony, all the flags and banners of Hian Tian Siang Tee's grandeur were taken out and placed at the main door of the temple. The flags of smaller black triangles are also widely displayed and this is more devoted to the flag of the tangsin who will descend into the medium of the god Hian Tian Siang Tee. The totem reverence in the ceremony is visible on the flag, namely the black flag and the cardinal directions, namely north.

The main features of Hian Tian Siang Tee 玄天上帝's appearance apart from the black color and the taiji (太極), / yinyang (陰陽) emblem depicted on the flag, are turtles and snakes. The two animals are depicted together in the form of a statue of Hian Tian Siang Tee, and are under his feet. The turtle and the snake have a symbolic meaning, which is the symbol of the stomach's desire for the world and the temptation of the mind. This human intention was conquered and trampled on by Hian Tian Siang Tee, who intended for humans to imitate him. In hunger for worldly desires and temptations, human beings can overcome them. Turtles and snakes are two demons that Hian Tian Siang Tee 玄天上帝 conquered as a symbol of the conquest of sloth and sluggishness; two things that can hinder humans from reaching truth and authenticity. In the end, if man overcomes both temptations by following the ending of the story of the turtle and snake, it can become a symbol for long life and virtue.

Apart from Heidi, the rows of banners or flags also embodied the shape of the totem. The flag line is symbolized as a warlord who is leading the troops to expel all negative things. The flags are also used to invite the gods in the five directions. The five flags with different colors indicate the five cardinal directions and the five elements of human life. The five colors are green which shows the direction of the east eye or the wood element, red shows the south direction and the fire element, white (light purple) shows the west or the metal element, black shows the north direction or the water element and yellow shows the southeast direction or the earth element.

In Hok Lay Kiong, the black color as a symbol of the north appears on the banners of the Hian Thian Siang Tee flag. In this one-time ceremony, all the flags and banners of Hian Thian Siang Tee's grandeur were taken out and placed at the main door of the temple. The flags of smaller black triangles are also widely displayed and this is more devoted to the flag of the tangsin who will descend into the medium of the god Hian Thian Siang Tee. The totem reverence in the ceremony is visible on the flag, namely the black flag and the cardinal directions, namely north. The main features in the appearance of Hian Thian Siang Tee 上帝 apart from the black color and the taiji (太極), / yinyang (陰陽) symbols depicted on the flag, are turtles and snakes.

The use of totem in Chinese culture modern tradition is can bee seen in temple's ceremony. The temple's ceremony represent totem as a sacred. In the ceremony at Hok Lay Kiong temple, the use of totems in the religious practices of Bekasi Chinese is seen. Totems can reflect sacred and profane manifestations such as in the celebration of a god through the use of the flags of the Hian Thian Siang Tee greatness. At a moment, these objects become sacred because they are used as a means for the medium to carry out the process of changing from profane to sacred, and are performed in the main place, namely in the temple. But in ordinary times, when it is not a short ceremony, these objects are kept and become something profane. The totem in Chinese culture, according to its history, has existed since before the period of certainty in China. In history in China, the totem occupies an important position in life, has an important role in the development of civilization and tradition. In ancient times, humans had hopes and desires to live better and get happiness, but this was difficult to achieve so that in real life, they always put their hopes 
on the totem symbol as a compensation for needs, that is, compensation as a major part of traditional social functions. helping people to pursue glory, prosperity, security and so on. The totem becomes hope and prayer in traditional Chinese society.

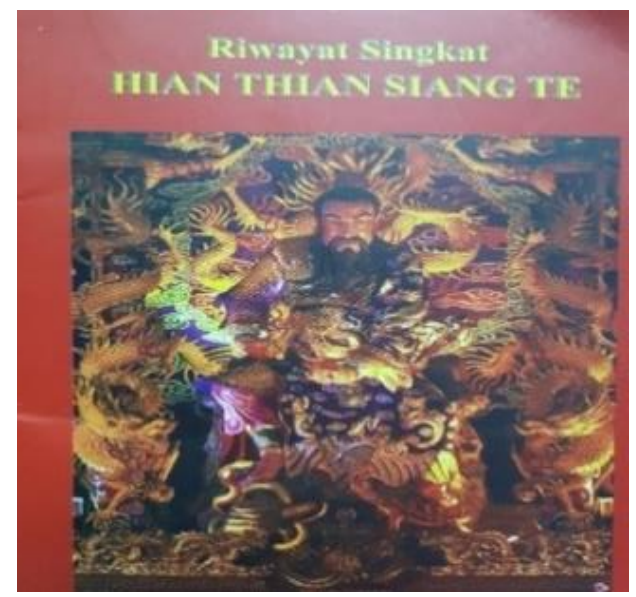

Fig 1. Brief History Book of Hian Tian Siang Tee, Hok Lay Kiong Temple

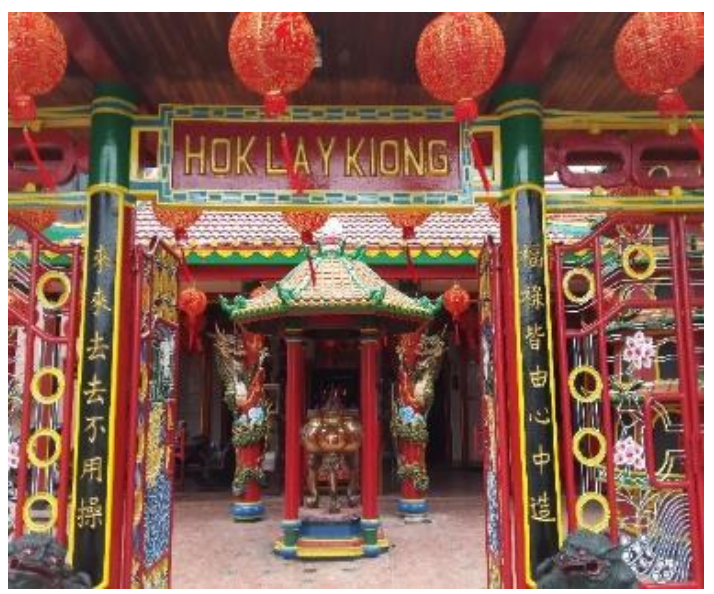

Fig 2. Hok Lay Kiong Temple

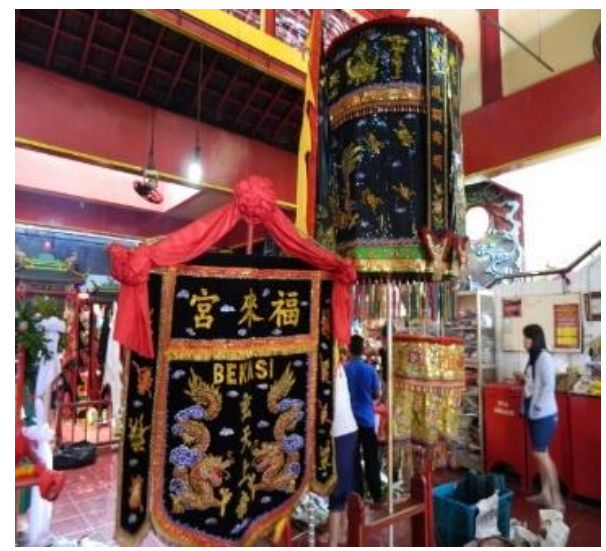

Fig 3. The temple's greatness banner

\section{Conclusion}

The Chinese totem as the embodiment of a favorable concept is one of the important components of folk culture and is also a reflection of the spirit of the Chinese character to pursue a happy life. The Chinese totem is a cultural symbol and cultural object 
that has developed in its long history. The traditional Chinese totem embodies the profound ideas of the Chinese people's worldview and becomes a cultural heritage.

The use of the totem in the form of the banner of the greatness of the Hok Lay Kiong temple, the black flag, the symbol of the turtle is a sign of something sacred and profane. In addition, the spirit of togetherness is reflected and becomes a form of solidarity to create an identity, namely his identity as a Bekasi Chinese who practices Chinese religious beliefs. in its function as a function of religion, social, culture and art.

\section{References}

[1] Rudyansjah T. Emile Durkheim Pemikiran Utama dan Percabangannya Ke Radcliffe Brown, Fortes, Levi Strauss, Turner, dan Holbraad. Jakarta: Penerbit Buku Kompas; 2015. 104 p.

[2] Allan S. Sons of Suns: Myth and Totemism in Early China. Bull Sch Orient African Stud. 1981;44(2):290-326.

[3] Durkheim É. The Elementary Forms of the Religious Life [Internet]. $1912 . \quad$ p. $456 . \quad$ Available from: https://books.google.com/books?hl=en\&lr=\&id=eEk1AwAAQBAJ\&pgis=1

[4] Rudyansjah T. Emile Durkheim Pemikiran Utama dan Percabangannnya ke Radcliffe Brown, Fortes, Levi Strauss, Turner, dan Holbraad. Jakarta: Penerbit Buku Kompas; 2015. 105 p

[5] Jianjun S. Auspicious Birds and Beasts. Tianjin: People’s Publishing House.; 2001. 34 p.

[6] Dong X. Application of Chinese Traditional Auspicious Patterns in Logo Design. 2015;189(Mehss):107-11.

[7] Yuanqin PENG. A Brief Introduction to Chinese Mascot. Can Soc Sci. 2012;8(6):2.

[8] Qiao D. Illustrated Handbook of Chinese Mascots. Beijing: Social Sciences Press; 2008. 4 p.

[9] Qiao D. Ilustrated Handbook of Chinese Mascots. Beijing: Social Sciences Press; 2008. 3 p.

[10] Qiao D. Ilustrated Handbook of Chinese Mascots. Beijing: Social Sciences Press; 2008. 4 p.

[11] Qiao D. Ilustrated Handbook of Chinese Mascots. Beijing: Social Sciences Press; 2008. 24 p.

[12] Bruun O. An Introduction To Fengshui. Cambridge: Cambridge University Press; 2008. 20 p 